\title{
Firm Characteristics and Capital Structure of Small and Medium Enterprises in Kenya
}

\author{
Mugwe Munga Michael ${ }^{1}$, Daniel Makori ${ }^{2}$ \\ ${ }^{1,2}$ Department of Accounting and Finance, School of Business, Kenyatta University, Kenya
}

\begin{abstract}
Small and Medium Enterprises play an important role towards economic growth and development in Kenya at large. However, there is limited evidence on their capital structure or how they take financing decisions in Kenya. It was therefore imperative to understand how key firm characteristics affect capital structure of these enterprises to help in improving policy decisions and offering practical guidance. This study investigated firm characteristics which influence capital structure of SMEs focusing on Kenya with the hope that findings and recommendations will be replicated in in other countries. Ordinary Least Square model was applied on Kenya's latest enterprise survey data of 2018.Both descriptive and regression analyses were employed. Results indicate that firm size and firm age are negatively associated with the capital structure. On the other hand, the study found that firm performance and assets base, affected capital structure positively. The study concludes that SMEs should find alternative funding avenues rather than relying on borrowing. A further study was also recommended to analyse why firm performance was positively related to capital structure.
\end{abstract}

Key words: Firm Characteristics, Capital Structure, Firm Size, firm age, tangible assets, firm performance, Small and Medium Enterprises in Kenya

DOI: $10.35942 / \mathrm{ijcab} . v 3 \mathrm{iV} .60$

Cite this Article:

Mugwe, M., \& Makori, D. (2019). Firm Characteristics and Capital Structure of Small and Medium Enterprises in Kenya. International Journal of Current Aspects, 3(V), 42-56. https://doi.org/10.35942/ijcab.v3iV.60

\section{Introduction}

Research globally, show that political instability, finance and crime directly affect growth rate of firms, finance leading as the most forceful variable affecting the rate at which firms grow. Further, indications argue that Small and Medium Enterprises (SMEs) suffer higher financing hindrances unlike large enterprises(Ayyagari, Demirgüç-Kunt \& Maksimovic, 2010a). Moreover, studies suggest that small firms do not use a lot external finance such as bank finance (Ayyagari, Demirgüç-Kunt, \& Maksimovic, 2011b; Kimuyu \& Omiti, 2000; Ondiege, 1996). Further evidence suggest that financial limitations hinders the average size of a firm (Lundvall, Ochoro, \& Hjalmarsson, 1998), and describes the vital importance of examination of the utilization of external finance in relation with SMEs. Globally, SMEs play a critical role towards GDP because they are the vast majority. For instance, in case of European Union (EU), $99.8 \%$ of all businesses are SMEs and are accountable for slightly more than two thirds or $67.4 \%$ of jobs (European Commission, 2017). Central bank of Kenya gave a report showing that $98 \%$ of firms are in the SMEs category (African Review of Business Technology (ARBT), 2018). In addition, this report argues that SMEs create $30 \%$ of the jobs yearly, and their contribution to GDP is about $3 \%$. According to the 2014 survey report, a total of eighty per cent of around 800,000 jobs generated in that year, originated from the informal industry, where SMEs are dominant (ARBT, 2014). 
The numerous theories and empirical research that exist in literature that attempt to describe the nature and factors affecting capital structure of firms largely originate from developed economies. This literature mainly focuses on big firms which offer complex financial assets for debt and equity equally (Olwale\&Asah, 2011). Additional attempts have also been made to understand the capital structure of enterprises in developing economies. This emergent research does not inherently explain whether arrived conclusions are applicable to developing economies or not (Lemmon \& Zender, 2010). There are various definitions of capital structure in various literature. Schnabel (1992) defined capital structure broadly as the use of both formal and informal debt. On their part Muiru and Kamua (2014) described capital structure simply as leverage (debt to total equity). The World Bank uses proportions to estimate how SMEs use different sources of finance. Overall, capital structure has been assessed differently in literature which may probably explain variations in study findings (Forteet al., 2013).

Generally existing research indicate that small enterprise in developing economies do not source external finances (Forteet al., 2013). For instance, less than 10\% of the small enterprises access bank credit (International Centre for Economic Growth (ICEG), Kimuyu \& Omiti, 2000) and therefore most of them end up using more of internal finance sources than external finances such as from friends and relatives or customer advances (Bhaird \& Lucey, 2010). For the need of precision in this study, leverage was taken to mean capital structure. Several studies have been conducted to establish how firm characteristics affect capital structure of small enterprises. Generally, existing studies indicate that asset structure, performance, size and age of SMEs affect capital structure of small enterprises (Schnabel, 1992). Similar studies have also been replicated in developing countries including Kenya (Muiru \& Kamua, 2014). A growing body of research in developed nations indicates that firm characteristics including the ones incorporated in this study greatly determine the leverage of the business (Bhaird\&Lucey, 2010; Dogra \& Gupta, 2009).

The firm's number of employees significantly influences capital decisions (Bhaird \& Lucey, 2010). Large companies are much diversified due to their cash flows stability and they do not experience high failure rates. Additionally, large firms have the advantage when it comes to debt acquisition due to availability of tangible assets against which debts are issued by most lenders. Therefore, large firms are capable of taking on more debt and can borrow at better conditions (Degryseet al., 2010). Smaller firms, on the other hand, experience difficulties in raising long-term finances due to unavailability of tangible assets to use as collateral; they have less stable cash flows and lack the necessary management skills. In addition, small companies are believed to have greater bankruptcy costs in comparative terms. Therefore, firm size and leverage relates positively. Newer firms rarely use debts compared to large firms suggesting a positive relationship between the age and the leverage of a firm. Young firms lack well established track records and thus the information asymmetry problem arises with external financiers (Dogra \& Gupta, 2009). Young firms should therefore select internal funding instead of private debt, suggesting existence of a positive association among age and the leverage of an SME. Relative to mature firms, younger firms need supplementary finances for growth and expansion. Newer firms don't access credit with ease compared to old firms. Additionally, they generate fewer profits, and they are in most cases not diversified compared to older firms and they are likely to experience higher rates of financial distress or bankruptcy. The trade-off hypothesis argues that newer SMEs prefer leverage compared to large firms. This creates a positive relation between the age of a firm and the leverage of the firm. Informational asymmetry among the insiders and the outsiders for young firms are more pronounced because they do not have well established track records. 
In connection to this theory, firms of such nature should source funds from within and not private debt. This will lead to a positive relationship between the age of a firm and the leverage of the firm. Firms with valuable firm assets which are capable of being used as collateral, in most cases end up using high debts. There is much empirical evidence that the asset structure of a firm was positively related to debt. These studies show that availability of tangible assets has a positive relationship with the use of debts in a firm. Firms which have many valuable tangible assets, will always borrow additional debts. This implies that availability of tangible assets has a role to play regarding firm financing decisions. Borrowing costs can be prohibitively high for firms will less tangible assets (collaterals), and therefore, their availability increases chances of firm borrowing. A positive relationship is therefore expected between capital structure and firm assets. Relationship between the performance of a firm and the leverage of a firm has been a highly contentious issue. There is a general belief that the organizations with high profits are expected to use high debt (Muiru \&Kamua, 2014).Profitable firms that have stable sales are highly ranked when it comes to payments of interests on loans of meeting the interest payments and they also make use of tax exemptions. Then again, there is evidence in empirical literature that profitable firms are fold of using internal funds to a great extent (Bhaird \& Lucey, 2010). This implies that firms with high profits incline to use internal financing than external financing, implying that profitability of a firm affects leverage negatively.

A major concern of existing studies is the general neglect of the central role of the owner and /or manager of a small enterprise as a decision maker. Evidence imply that owners of SMEs can determine its capital structure particularly based on the need for the control of the enterprise (Myers, 2009). Therefore, the basic characteristics associated with owners and managers of small enterprises need to be clearly identified as determining factors of the capital structure of small enterprises. Research therefore needs to be carried out to clearly find the elements that influence the capital structure of small firms. This study will establish how firm characteristics affect the leverage of small enterprises. The significance of this study was to present new evidence of determinants of capital structure of SMEs in developing economies specifically Kenya. SMEs contribute fundamentally towards the growth and development of the economy of Kenya (Government of Kenya, 2005). This is by the argument that SMEs develop unique business gaps during early economic development stages. As a result, employment and wealth are created. For instance, in the year 1999 there were approximately 1.3 million small businesses operating in Kenya (ARBT, 2018). After four years, SMEs were predicted to have employed 5.1 million persons (Government of Kenya, 2003) and these enterprises employed 15,160.8 thousand people in 2015 (Government of Kenya \& Kenya National Bureau of Statistics, 2016). Moreover, SMEs are taken to be essential in encouraging entrepreneurial culture and technological awareness(Government of Kenya, 1986). The progress of the SMEs is therefore critical in promoting economy of Kenya.

\section{Statement of the Problem}

In most cases SMEs are undercapitalized, signifying a major operational struggle as far as accomplishment of organisational goals are concerned. Olwaleand Asah (2011) observed that $58.4 \%$ of the small businesses in Kenya quote the availability of market as the most severe hindrance to the growth of SMEs followed by the availability of external funding. Further, Muiru and Kamua (2014) cited that SMEs access to external finance is connected to better performance of small and medium enterprises. Moreover, Muiru and Kamua (2014) indicated that small and medium enterprises which that operate with insufficient funds due to lack of external funding are in most cases less productive and do not operate at optimal levels. Muiru and Kamua (2014) further noted that SMES in Kenya have challenges in accessing external 
finances. The result of this is that since SMEs are challenged in getting external finance, then their role in developing and growing the economy of the country is at risk.

A number of studies have been undertaken to establish the aspects affecting capital structure of small enterprises. Generally, existing studies indicate that firm characteristics as well as profitability, asset structure, firm size and age influence the capital structure of small enterprises (Bhaird\&Lucey, 2010; Degryseet al.,2010; Olwale\& Asah, 2011). Such studies have also been replicated in developing countries including Kenya (Dogra \& Gupta,2009; Muiru\&Kamua, 2014). Findings reported in existing literature are largely contradicting (Frank and Goyal, 2009). Some literature show that capital structure is affected by firm characteristics (Degryse et al., 2010) while others fail to show evidence of the relationship (Muiru \& Kamua, 2014). While others found positive relationships Gaud, Jani, Hoesli and Bender (2005), others found negative relationships Wintoki, Linck, and Netter (2012). Inconsistencies have partly been traced on methodological issues majorly differences in measurement of variables and study designs. This study will make use of appropriate study methods and measurements of variables as discussed in chapter three.

Further conclusions from research indicate that there exist some similar traits in capital structures applied by firms of different sizes in various countries. In developed nations SMEs have been shown to have distinct capital structures from that of large enterprises. Emerging but limited evidence further suggests that SMEs in developing countries haveunique traits and financing challenges that give rise to peculiar capital structure approaches (Ayyagariet al., 2010). This therefore creates doubt on the effectiveness of replicating studies on capital structure from developed economies in developing economies. The research carried out so far to document the causes of different choices of capital structure taken by SMEs in developing countries is contradicting. Specifically, current studies do not provide information on the specific factors affecting capital structures of SMEs in developing countries. Therefore, it was essential to make out the specific aspects influencing choice of capital structure of SMEs in developing countries so that to help in improving policy decisions and offering practical guidance. It is against this background that this study re-focuses attention to investigate how firm characteristics influences the choice of capital structure among SMEs in Kenya, a third world country.Predominance of SMEs in Kenya underscores the need for more attention to revisit capital structure associated with such small and medium enterprises. In response to the importance of gap of highly contradicting findings between the few empirical studies associated with capital structure of SMEs located in Kenya and their counterparts in the developed economies, this article looks at specific firm characteristics of capital structure of SMEs using a sample of firms in Kenya.

\section{Objectives of the Study}

To establish the effect of firm characteristics on capital structure of SMEs in Kenya.

Specific objectives were:

i. To determine the effect of firm size on capital structure of SMEs in Kenya.

ii. To examine the effect of firm age on capital structure of SMEs in Kenya.

iii. To establish the effect of tangible assets of a firm on capital structure of SMEs in Kenya.

iv. To determine the effect of firm performance of a firm on capital structure of SMEs in Kenya. 


\section{Theoretical Review}

\subsection{Pecking Order Theory}

This study proposes to use one of the most leading theory of capital structure advanced by(Frank \& Goyal, 2009), called the pecking order theory (Myers, 1999; Myers \& Majluf, 1984). Briefly, this theory guesses that the choice of funding sources follows a ranked direction. Accordingly, any given enterprise tends to make use of internally generated funds instead of external funds. Furthermore, firm prefers debt to equity. Consequently, in order to attain the key objective of maximizing wealth, enterprises run away from costs associated with information asymmetry and hostile selection. Therefore, pecking order theory can be explained in the view of transaction costs and also the view of asymmetric information. Basic tenets of the pecking order theory convincingly show how it might apply naturally to SMEs (Schnabel, 1992). To begin with, it is obvious that the decision makers in most cases put the will of shareholders first: the company manager is largely its initiator and he is the key shareholder. Additionally, the leading position of the manager being the key shareholder, advanced mortality level, limited diversification and inadequate supervisory necessities for the publication of quantitative information translates to SMEs suffering from less experience to the matters of information asymmetry and consequently the adverse selection. Further, sources of financing such as bond markets are not accessible by SMEs. These concerns, together with other cases such as the integration of family and also company patrimony, the elasticity of funding, and also some sort of individuality, explain why the managers of SMEs prefer internal financing. Managers and shareholders tend to use internal funding in attempt to retain the controlling rights of the enterprise and also the need to evade capital delusion. In some SMEs, managers prefer slow growth instead of losing the control of the firm. Therefore, equity financing becomes the last option for most SMEs.

\subsection{Modigliani-Miller Theorem}

The theory is in a series of articles that begun in 1958 and was propagated by Modigliani and Miller. The Modigliani-Miller theorem is the proposal regarding capital Structure that possibly developed the foundation of current philosophy pertaining capital structure. The proposition argues that in case there is no agency cost, tax does not exist, no case of information asymmetry and the market is efficient, then the capital structure is irrelevant to the firm value. Therefore, firm value is independent of dividend policy and capital structure choice. This scenario is referred to as capital structure irrelevant principle. Modigliani-Miller theorem was advanced in a domain where taxes don't exist. Basically, the theory argues that the value of the firm is not affected by capital structure of a firm. The theory has two prepositions, the first ignores taxes and the second considers taxes. Nevertheless, supposing we are in a world where taxes are charged and the interests on debt are tax deductible. Disregarding other factors, then the value of firm would be directly proportional to the amount used as debt. Therefore, the increase in firm value is associated with increase in amount of tax saved due to use of debt instead of equity. Take a case of two similar firms with different. One firm is unlevered, meaning that it is financed by equity wholly. The second firms is financed partially by debt and partially by equity. The Modigliani-Miller theorem Preposition 1 concludes that a firm financed through equity and another financed by both equity and debt are same. It has been criticised on the basis that it ignores taxes, transaction costs and bankruptcy costs. The second preposition suggests that in the presence of taxes, a firm financed through equity and another financed by both equity and debt are similar. This contrasts with studies that consistently indicate that the value of a firm is affected by its source of finance. In addition, this theory only considers equity and debt leaving out the injection of finances from internal sources, friends, relatives and customer 
deposits, practices that are common in developing countries. In developing countries, community matters compared to developed countries where individualism prevails (Ghana and Kenya). Hence this theory may not be appropriate in developing countries.

\subsection{Agency Theory}

According to this theory, behaviours of various agents such as managers and shareholders determine the funding of a firm. Managers may resist high levels of debt in cases where they feel their jobs and incomes are at risk. On the other hand, owners prefer riskier projects since they have potential to generate high returns. Financing policy can offer shareholders with a means of reducing value reducing behaviour of management and hence reduce agency cost. The converging of interests between the management and shareholders has been shown to reduce agency cost. Subsequently, optimal capital structure is achieved through reconciliation of conflicts of interests between managers and owners. However, managers and owners of small firms are usually one and the same in most small enterprises. Thus, this theory may not be directly appropriate in studies on the capital structure on SMEs.

\subsection{Trade off Theory}

The theory suggests that the choice of debt or equity depends on the costs and benefits associated with each source. It weighs the benefits of debts verses the costs of borrowing. Costs associated with debts include bankruptcy, interests and poor relationship with bank. Benefits of debt include among others the discipline on managers and tax allowances on interest payments. When the marginal tax benefit and marginal cost related to bankruptcy are equal, then the most favourable capital structure is achieved. Therefore, firms prefer debt over equity up to the point where the probability of financial distress and bankruptcy outweigh the tax benefit. The bank managers of small firms might lack the capability to weigh the benefits and costs. Further, financial markets tend to be volatile and managers may not have the tools to take care of the resultant uncertainties. Often, equity financing is used by large corporations and enterprises and not small and medium enterprises. Therefore, this theory does not explain capital structure decisions on small and medium enterprises conclusively.

\section{Empirical Review}

Some growing empirical effort have been devoted to examining the nature and determinants of the capital structure of small enterprises. Much of the research has originated from developed economies (Menike, 2015). No much research is documented to establish the nature and determinants of capital structure in evolving countries. This study reviews these empirical studies based on specific objectives.

\subsection{Effect of Firm Size of SMEs and the Capital Structure of SMEs.}

There are several studies which investigated capital structure and firm size in both developed and developing countries. For example, in applying ordinary least square (OLS) method on firm-based and market data for firms in Switzerland, Lemmon and Zender (2010) observed that the size of the firm determines financing decisions of an enterprise. However, though the coefficient of the firm size was significant, its size was small meaning that it weakly explains firm leverage decisions. One short coming of this study was that OLS method does not control for endogeneity and therefore, the estimates could have been biased. This study will employ logistic regression which try to control for endogeneity challenges. A study conducted by Wintoki, Linck, \& Netter (2012) for the case of Mexico established that size of the firm influences its capital structure negatively, contrary to conventional expectations. In a study which employed survey data of 201 small and medium-term enterprises, total assets were used to measure firm size. It is not easy to get information on the assets and therefore, 
this could have led to a negative relationship between capital structure and the size of the firm. This study will use the World Bank recommended measure of firm size, i.e. number of employees which is much easier to obtain information from the respondents.

Using a data base of 19,000 Brazilian based SMEs drawn from the state of Sao Paulo, Forte et al., (2013) investigated the factors influencing the choice of capital structure. This study employed system Generalized Method of Moment estimator on longitudinal data for 13 years which established positive but, weaker relationship between firm's capital structure and the firm size. Additionally, this study established firm age and firm profitability to be negatively correlated with the financial decisions of SMEs, while asset growth and capital structure indicated a positive relationship. Studies by Hernadez et al. (2011) for the case of Italy, Hair et al. (2012) for China on the determinants of capital structure did establish that the size of a firm explains capital structure positively. These studies applied logistic regression methods on survey data which also found that profitability and asset structure of a firm were positively related to firm financing decisions. Furthermore, they established that a negative relationship existed between a firm capital structure and the firm age. However, both the studies carried out investigation on larger firms. This study will investigate the role of firm characteristics on capital structure in the context of SMEs.

\subsection{Effect of the age of SMEs on the Capital Structure of SMEs.}

Empirical evidence regarding the role of age of a firm and financing decision is inconclusive. While some studies have established a positive relationship, others have found a negative one. For example, Saarani and Shahadan (2012) using a panel data from 2004 to 2011 for Malaysian firms to investigate factors influencing determination of capital structure in both small firms and large enterprises. The study used a sample of 285 firms and found that the age of firms was negatively correlated to capital structure for both SMEs and large firms in Malaysia.in addition, while size of the firm was positively correlated to capital structure for both SMEs and large firms, the study found that profitability was negatively related to capital structure in the case of large firms. However, age of the firm was calculated from the date a registration certificate was received. Some firms may have not started their operations immediately. This study will measure the age from the day the firm was licensed to begin its operations.

In using variety of methods: Partial Least Squares, Structural Modelling Equations and multiple linear regressions, Palacin-Sanchez et al., (2013) for the case of Spanish firms, found that age a firm is negatively correlated with firm financing decisions. This revelation was consistent with pecking order theory indicating that firms with many years of operation, have less loans because of their huge potential in generating funds internally. Similar results were observed by Hernández-Cánovas and Martinez-Solano (2011) and (Bhaird \& Lucey (2010). Degryse and Kappert (2010) investigated capital structure and its determinants for the case of Croatia using unbalanced panel data covering 2005-2011 for 500 SMEs. The study employed both fixed and random effects models. Apart from the age of the firm, other determinants of capital structure investigated included profitability, asset structure, and industry characteristics. The study established that a positive relationship between firm leverage decisions and the age of the firm. Similarly, there was a positive correlation between capital structure and firm profitability and asset structure, while with regard to industry dummy variable, the outcome was negative. Using Partial Least Square Method, Alex and Zhonghi (2012) established that the age of the firm influences the capital structure of firms positively. In this study, firm's age was measured as the date of registration. This is a weakness due the fact that in some cases, there is time lag between date of registration and commencement of the business. This is likely to affect the findings. This study proses to use 
date of commencement of the firm as a measure of the age of a firm. In a similar study, Hair and Ingle (2012) on their part, found a negative correlation between firm age and firm capital structure.

\subsection{Effect of the tangible assets on the Capital Structure of SMEs}

Empirical literature has also delved into the role played by tangible assets on firm's capital structure, where many studies seem to support positive relationship between firm's assets and its capital structure and hence implying, assets increases firm's potential to access credit. A study by Kamau and Mwangi (2015), established that assets influences firm's capital structure positively. However, this study employed OLS regressions which could not have controlled for endogeneity challenges. Similar findings were recorded by $\mathrm{Wu}$ and Zeng (2008) for the case of China. Nevertheless, unlike Gaud, Jani, Hoesli, \& Bender (2005), Wu and Zeng (2008) used Generalized Method Moment systems which have the potential to control for endogeneity as well as multicollinearity problems. In an empirical study on the determinants of SMEs capital structure in Punjab India, Dogra and Gupta (2014) argued that the firm's asset structure matters a lot when it comes to financing decisions. In a study which applied OLS regressions on survey data for 270 SMEs, the study observed that firm's tangible assets are positively related to capital structure. Furthermore, this study established that while the age of a firm was negatively correlated with financing decisions, firm's profitability in contrast, had a positive relationship with capital structure. Lemmon and Zender (2010) found that small and medium firms use some of their tangible assets as collateral to obtain credit from financial institutions or to reduce their costs in a way that assets acts as a guarantee in the case of loan default. This study applied both random and fixed effects regressions on a five-year panel data (2004-2009). The results indicated that firm's asset structure, age, profitability and size were all positively related to financial decisions (capital structure). Similarly, Dewatripont, Legros and Matthews (2003) noted that firm's assets reduce selection and moral hazard costs.

\subsection{Effect of firm performance on the capital structure of SME}

There are several studies on the association of firm performance and firm capital structure. However, empirical evidence found hear is inconclusive due to mixed findings. A study in the case of Brazilian SMEs to establish determinants of financing found that profitability was negatively correlated to capital structure (Forte et al., (2013). In this study which had a sample of 19,000 firms and employed Generalized Method of Moments to a panel data of 13 years, also established that firm assets were positively related to leverage. These conclusions support pecking order theory which argue that businesses tend to fund their operations through loans only after maximizing the internal sources. Furthermore, this study found that firm size, though being positively related to firm leverage, such effect was weak. Olwale and Fatoki (2011) conducted a study to establish the influence of firm characteristics and entrepreneurial traits affecting financial decisions in South Africa. Using survey data, and applying logistic regressions, the study found that age, size, and profitability of a firm influenced it leverage positively. One of the short coming of the study was study it did not account for endogeneity problem for which this study will address. Negative connection between capital structure and firm's performance was justified by pecking order theory proposed by Myers and Majluf (1984). This is according to the study conducted by Henseler and Inkovi (2009). In this situation, enterprises prefer to use internally generated funds to finance their operations. These internal funds are not subject to undervaluation by capital providers from outside or controls. However, this assertion is mostly relevant to privately owned SMEs because they have less stringent controls from the government. 


\section{Conceptual Framework}

Figure 1 below illustrates a conceptual framework that chronicles the relationship between firm characteristics and capital structure of SMEs. It highlights the set of factors that have been proposed variously in literature as relevant to capital structure decisions. Four characteristics of the firm namely firm age, firm size, firm tangibility and firm performance have been recognised in literature as close determinants of capital structure in SMEs and are shown to be direct determinants of capital structure of SMEs.

\section{Independent variables}

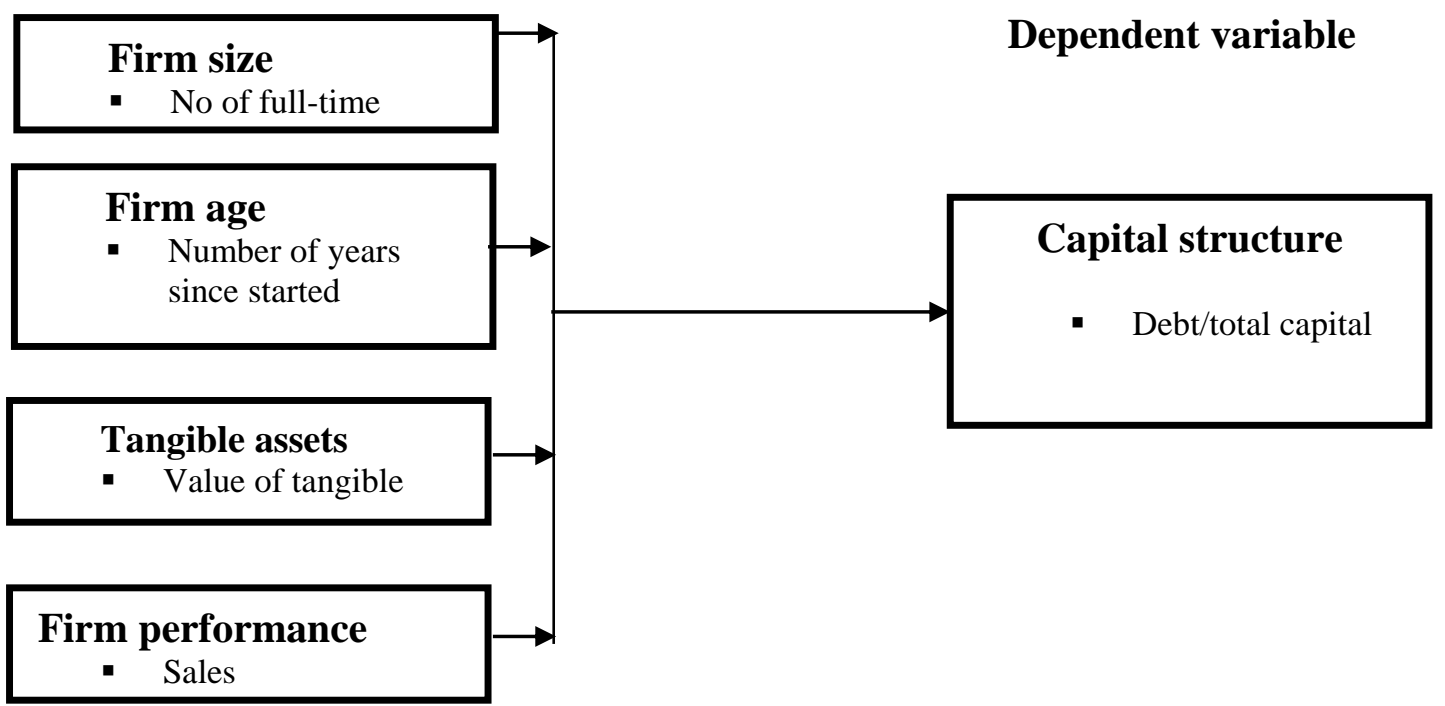

\section{Figure 1: Conceptual Framework}

Source: Author (2019)

\section{Research Methodology}

Correlation survey design was adopted in this project to study the objectives. The study was conducted with the aim of probing how firm characteristics affect the choice of capital structure among SMEs. This study design was expected to offer the status quo of SMEs. Both correlation and regression analyse were conducted in an attempt to study determinants of capital structure successfully used the same. OLS regression was used as the model of conclusively determining the correlates of different sources of finance in SMEs. This model took the form:

$$
\mathrm{y}=\beta \mathrm{x}_{\mathrm{i}}+\mathrm{e}_{\mathrm{i}------------------------------------------------(1)}
$$

Where $y$ refers to the ration between firm's debt and total equity, $\beta$ are the regression coefficients, $\mathrm{x}_{\mathrm{i}}$ are the correlates and $\varepsilon_{i}$ is the estimation error. Model (1) was further be expanded as:

$(\text { leverage })_{i}=\alpha_{0}+\beta_{1}(\text { fsize })_{i}+\beta_{2}(\text { fage })_{i}+\beta_{3}(\text { fassets })_{i}+\beta_{4}(\text { fperformance })_{i}+$ $\varepsilon_{i} \ldots \ldots \ldots \ldots(2)$

Where:

Leverage is taken to be ratio of debt compared to total capital in a given SME.

$\alpha$ is the intercept of the regression model which also captures unobserved characterises. 
$\beta_{1-} \beta_{4}$ represent the slope coefficients for the variables that are independent

fsize represent the size of a firm

fage is the age of a firm.

fasset stand for the assets of a firm.

fperformance is the firm performance

$\mathcal{E}$ is the error term.

The study focused on Kenya. The country has many SMES operating many economic activities ranging from manufacturing, retail and service industry driving the county. The country has an estimated of 1.3 million SMEs according to (KNBS, 2016). Most of these 1.3 million SMEs fall under the category of SMEs as defined in this study i.e. SMEs with number of employees not exceeding 99.

The sample for this data was selected through stratified sampling technique. Three strata were used, that is, industry (manufacturing and service), firm size (based on number of employees), and geographical region (Nakuru, Nyanza, Central, Mombasa and Nairobi). Sampling frame was obtained from census of business enterprises, KNBS 2012. A total of 1001 establishments were found eligible for the survey and was used as the sample size for the study. The other sectors which command a relatively bigger market share include the wholesale sector, 54 (5.64\%), construction, 48 (5.01\%), chemicals, $46(4.80 \%)$, plastic and rubber at $3.97 \%$ and garments at $3.05 \%$. These statistics indicate that textile, non-metallic mineral products, transport and recycling industries constituted about $2 \%$ each of the sectors surveyed by the World Bank. All other remaining sectors recorded less than 2\% of the SMEs surveyed. This study made use of descriptive as well as inferential statistics to analyse data. Descriptive statistics such as means, standard deviations, minimum and maximum were generated. On the other hand, OLS regression and correlation analyses were conducted for inferential purposes using Stata version 14.0 software. Further, the results were presented using tables, percentages and graphs. Results were estimated using OLS model.

\section{Study Results}

The study conducted a correlation analysis to find out how the dependent variable (leverage) was related to the explanatory variables (firm size, age, assets and performance). Summary results are presented in Table 1.

Table 1: Correlation Results

\begin{tabular}{|c|c|c|c|c|c|c|}
\hline & leverage & firmsize & tassests & fage & \multicolumn{2}{|c|}{ performance } \\
\hline leverage & 1.0000 & & & & & \\
\hline firmsize & 0.0768 & 1.0000 & & & & \\
\hline tassests & 0.0564 & 0.0180 & 1.0000 & & & \\
\hline fage & 0.0207 & 0.0289 & -0.0106 & & 1.0000 & \\
\hline performance & 0.0312 & 0.0873 & -0.0071 & & 0.0066 & 1.0000 \\
\hline
\end{tabular}

Source: Stata output (2019)

According to the correlation results presented in Table 1, the size of the firm proxied by number of full-time employees, total assets of the firm, and firm performance are all positively related to the capital structure (leverage). In addition, age of the firm has a positive relationship with capital structure. 
The aim of this study was to investigate effects of firm characteristics on capital structure focusing on SMEs in Kenya. To achieve this aim, the study had formulated four specific objectives. These were: to determine the effect of firm size on capital structure of SMEs, to examine the effect of firm age on capital structure of, to establish the effect of tangible assets of a firm on capital structure of SMEs, and to identify the effect of firm performance on capital structure of SMEs in Kenya.

To respond to these objectives, the study conducted a regression analysis with the aid Ordinary Least Square (OLS) method. The regression indicates the direction of the relationship and whether the relationship or the effect is significant or not. The hypothesis for the regression was that the coefficients of explanatory variables are different from zero, such that any p-value less than greater than $0.10,0.05$ or 0.001 could lead to rejection of the hypothesis.

The regression estimates on the determinants of SMEs capital structure in Kenya are presented in Table 2.

Table 2: Estimated Results

\begin{tabular}{|c|c|c|c|c|c|c|}
\hline Leverage & Coef. & Std. Err. & $\mathrm{T}$ & $\mathrm{P}>\mathrm{t}$ & $\begin{array}{l}95 \% \\
\text { Conf }\end{array}$ & Interval] \\
\hline Fage & -.0002388 & .000406 & -1.97 & 0.045 & $\begin{array}{l}- \\
.0002388\end{array}$ & -.000406 \\
\hline Fsize & $\begin{array}{l}-.0018877 \\
.0041155\end{array}$ & $\begin{array}{l}.0008368 \\
.0023935\end{array}$ & $\begin{array}{l}-2.26 \\
1.72\end{array}$ & $\begin{array}{l}0.024 \\
0.086\end{array}$ & $\begin{array}{l}.0002456 \\
-\end{array}$ & $\begin{array}{l}-.0035299 \\
.0088126\end{array}$ \\
\hline Fassetts & & & & & .0005816 & \\
\hline Performance & .5464123 & .1294086 & 4.22 & 0.000 & .2889773 & .8038472 \\
\hline _cons & .0385463 & .0138624 & 2.78 & 0.006 & .011342 & .0657507 \\
\hline Number of obs & 958 & & & & & \\
\hline Prob $>$ F & 0.000 & & & & & \\
\hline R-squared & 0.0058 & & & & & \\
\hline
\end{tabular}

Source: Stata output (2019)

Null hypothesis of the OLS model states that all the coefficients of the model are different from zero (0). According to the results in Table 4.10, the OLS model was well fitted based on the fact that the probability F-statistic (Prob > F) is less than 5\% (or 95\% confidence interval. This also indicates the acceptance of the null hypothesis. The R-squared estimate show that determinants of capital structure among SMEs incorporated in the study strongly explain the dependent variable. A value of 0.0058 means that a change in any of the explanatory variables (firm age, firm size, firm assets and profit) lead to $0.58 \%$ change in capital structure. The estimated leverage model equation 2 can therefore expressed as:

$$
\begin{aligned}
(\text { leverage })_{i}= & .0385463+-.0018877(\text { fsize })_{i}-.0002388(\text { fage })_{i} \\
& +.0041155(\text { fassetts })_{i}+.5464123(\text { performance })_{i}
\end{aligned}
$$

With regard to the effect of firm size on capital structure, the study has established that there is a strong negative relationship between the size of the firm and firm capital structure which was measured by debt/equity ratio. This is based on the fact that this variable is statistically significant at $5 \%$ confidence level given that its p-vale is 0.024 . Accordingly, the coefficient of firm size (fsize), -0.0018877 is negative. The size of this coefficient indicates that a unit change in fsize leads to about $0.189 \%$ decrease in debt equity ratio. These findings imply that bigger SMEs have fewer debts due to their ability to generate more internal finances probably 
through retained earnings. Additionally, bigger SMEs especially company limited by shares can raise funds by floating its shares on the Nairobi Securities Exchange (NSE).A study conducted by Wintoki, Linck, \& Netter (2012) for the case of Mexico realized similar findings where it was reported that firm size was negatively correlated with capital structure. However, this study used total assets as a measure of firm size. Contrastingly, Studies by Trovato \& Alfo (2006) for the case of Italy, Wu et al., (2008) for China on the determinants of capital structure did establish that the size of a firm explains capital structure positively.

An investigation into the effect of the firm age on capital structure was found to be significant at $10 \%$ confidence level. In addition, the two variables are negatively relatedmeaning that an increase in the age of the firm reduces debt/total equity ratio. However, the size of the coefficient (-.0002388) show a weaker linkage between firm capital structure and the age of the firm, which means that a unit change an increase in firm age leads to a reduced debt/total equity by about $0.02 \%$. These results mean that as the firm increases in age (years), leads to accumulation of more resources and probable generation of more internal funds (retained earnings). This finding is consistent with pecking order theory which states that firms with many years of operation, have less loans because of their huge potential in generating of internal finance. Other studies that have similar findings include studies by HernándezCánovas and Martinez-Solano (2011), Bhaird and Lucey (2010), and Saarani and Shahadan (2012). Contrastingly, Henseler and Inkovi (2009) found that the age of the firm influences the capital structure of firms positively.

Concerning the effect of SMEs tangible assets on the capital structure, the study found a positive and significant relationship between assets and capital structure. This is informed by the positive coefficient (0.0041155) and a p-value of 0.086 (less than 10\%) confidence intervals). This finding also indicates that the effect of firm assets on capital structure is weaker because, an increase in a unit of assets, leads to an increase in debt/total equity by about $0.41 \%$. The implication of the finding is that SMEs assets gives the firm a better base for borrowing due to the fact that firms use assets as securities to secure loans in financial institutions. Various studies have established similar results (Gaud, Jani, Hoesli, \& Bender, 2005; Wu \& Zeng, 2008; Lemmon \& Zender, 2010). Finally, the study also examined the effect of SMEs performance on the capital structure. The study found that the performance of SMEs in Kenya was positively related to the capital structure. In addition, the estimated coefficient was found statistically significantly at $1 \%$ confidence interval indicating a strong relationship. Furthermore, the size of the coefficient (.5464123) show that profits have a large impact on the firm capital structure, such that a unit increase in profits, leads to an increase in the capital structure by about 54.64\%. Olwale and Fatoki (2011) for the case of South Africa established similar results. However, studies by Forte et al. (2013) and Henseler and Inkovi (2009) argued that profitability of a firm impacts capital structure negatively. This implies that an increase in profits could reduce debt to total equity ratio.

\section{Conclusion}

Several conclusions are drawn from this study. First, size of the firm is very critical when it comes to the capital structure. That, bigger firms tend to borrow less as compared to smaller firms. Secondly, the study concludes that even though the age of a firm is negatively related to capital structure, it is not very significant. This means debt/equity ratio of a firm does not necessarily depend on whether an SME is young or older. Thirdly, the study concludes that firm assets are an important determinant of its capital structure. SMEs use assets at their disposal to secure loans from commercial banks and other financial institutions. Finally, the study concludes that majority of SMEs in Kenya may not be retaining their profits to finance 
their business. This could also mean, poor financial management. This could be the reason why, firm performance positively related to the capital structure.

\section{Recommendations}

According to the results, summary and conclusions, the following recommendations are proposed: Debts in most cases come at a cost (interest rate) and at times, they can be burdensome to a business enterprise. The study therefore recommends that SMEs should adopt debt reduction measures like use of alternative funding sources (share capital and retained earnings). Since performance was found to influence capital structure positively, contrary to the expectation, it will be imperative to do a robust investigation into the reasons why this was the case. The study could also incorporate other variables such as human capital development to see if they could change these results. This discovery here could lead to formulation of better policies which could improve SMEs performance.

\section{REFERENCES}

African Review of Business Technology. (2018). SMEs are Growing Kenya's Economy. Retrieved on $7^{\text {th }}$ July 2018 from: http://www.africanreview.com/finance/business/smes-are-growing-kenya-s-economy3

African Review of Business Technology. (2014). Kenya's Economic Environment. Retrieved on $7^{\text {th }}$ July 2018 from: http://www.africanreview.com/finance/business/smes-Kenyaeconomic-kenya-s-economy.

Alex, R.K., and Zhonghi, H. (2012). The Impact of Firm Characteristics in Access of Financing by Small and Medium-Sized Enterprises in Tanzania. International Journal of Business and Management, 7(24), 108-119

Ayyagari, M., Demirguc-Kunt, A., \& Maksimovic, V. (2006). How Important Are Financing Constraints? The Role of Finance in the Business Environment. World Bank.

Ayyagari, M., Demirgüç-Kunt, A., \& Maksimovic, V. (2010a). Formal versus Informal Finance: Evidence from China. The Review of Financial Studies, 23(8), 3048-3097. https://doi.org/10.1093/rfs/hhq030

Ayyagari, M., Maksimovic, V., \& Demirguc-Kunt, A. (2011b). Small vs. young firms across the world : contribution to employment, job creation, and growth (No. WPS5631) (pp. 1-43). The World Bank. Retrieved from: http://documents.worldbank.org/curated/en/478851468161354807/Small-vs-youngfirms-across-the-world-contribution-to-employment-job-creation-and-growth

Bhaird, C., and B. Lucey (2010). Determinants of capital structure in Irish SMEs. Small Business Economics, 35 (6), 357-375.

Degryse, H., P. de Goeij, and P. Kappert. 2010. 'The Impact of Firm and Industry Characteristics on Small Firms Capital Structure.' Small Business Economics 38 (4): 431-47.

Dewatripont, M., Legros, P., and Matthews, S. A. (2003). Moral hazard and capital structure dynamics. Journal of European Economic Association, 1(4), 890-930

Dogra, B., and Gupta, S. (2014).An empirical study on capital structure of SMEs in Punjab. The IUP Journal of Applied Finance, 15(3), 60-80.

European Commission (2017) European SMEs under Pressure: Annual Report on EU Small and Medium-Sized Enterprises 2009. available at: http://ec.europa.eu/enterprise/policies/sme/facts-figures analysis/performance review/pdf/dgentr_annual_report2010_100511.pdf. 
Forte, D., Ayres, L. B., and Toshiro, W. N. (2013).Determinants of the Capital Structure of Small and Medium Sized Brazilian Enterprises. Brazilian Administrative Review. Retrieved on 19/3/2018 at http://www.anpad.org.br/bar

Frank, M. Z., and Goyal, V. (2009). Capital Structure Decisions: Which Factors Are Reliably Important? Financial Management, 38(1), 1-37.

Gaud, P., Jani, E., Hoesli, M., and Bender, A. (2005). The capital structure of Swiss companies: an empirical analysis using dynamic panel data. European Financial Management, 11(1), 51-69.

Government of Kenya. (1986). Sessional paper No 1 of 1986 on Economic management for renewed growth. Government Printers.

Government of Kenya. (2003). Economic Survey. Nairobi: Government Printers.

Government of Kenya. (2005). Sessional Paper No. 2 of 2005 on Development of Micro and Small Enterprises for Wealth and Employment Creation for Poverty Reduction. Nairobi.

Government of Kenya, and Kenya National Bureau of Statistics. (2016). Economic Survey 2016. Nairobi: Government Printers.

Hair J.F. M., Pie er, and Ingle, C.M. (2012). The Use o Partial Least Squares Structural Equation Modeling in Strategic Management Research: A Review o Past Pra ti es and e ommendations or Future A li ations "Long Range Planning 45, 320-340.

Hernández-Cánovas, G., and Koëter-Kant, J. (2011). ME inan ing in Euro e Cross- ountry determinants o bank loan maturity, International Small Business Journal 29(5), 489507.

Henseler, J., C. M., Ingle and Inkovi, S. (2009). "The use o artial least squares ath modelling in international marketing. Advances in International Marketing 20 (5), 277-320.

International Centre for Economic Growth, Central Bureau of Statistics, \& K-Rep. (ICEG). National Micro and Small Enterprises Baseline Survey. Nairobi: ICEG.

Kamau, J. G., and Mwangi, M., N. (2015). Socio-Economic Determinants of Performance of Small and Medium Enterprises (SMEs) in Gilgil Town of Nakuru County, Kenya. IOSR Journal of Humanities and Social Science, 20 (8), 109-115

Kimuyu, P., \& Omiti, J. (2000). Institutional Impediments to Access to Credit by Micro and Small Scale Enterprises in Kenya. Nairobi: Institute of Policy Analysis and Research.

KNBS. (2016). Micro, Small and Medium Enterprises Survey Report. Nairobi: Government Printer

Lundvall, K., Ochoro, W. O., and Hjalmarsson, L. (1998). The Productivity of the Kenyan Manufacturing Sector. In The Structure and Performance of Manufacturing in Kenya. Washington DC.

Lemmon, M. L., and Zender, J. F. (2010). Debt capacity and tests of capital structure theories. Journal of Financial and Quantitative Analysis, 45(5), 1161-1187.

Menike, L.M.C. (2015). Capital Structure and Financing of Small and Medium Sized Enterprises: Empirical Evidence from a Sri Lankan Survey. Journal of Small Business and Entrepreneurship Development June 2015, 3(1), 54-65

Muiru, M., and Kamau, S. M. (2014). An Assessment of Capital Structure Decisions by Small and Medium Enterprises in Kenya. Research Journal of Finance and Accounting, 5(15), 20-27.

Myers, D. (1999). Text Writing at an Undergraduate College. Journal of Personality and Social Psychology, 20(7) 386-391.

Myers, S. C., and Majluf, N. S. (1984). Corporate financing and investment decisions when firms have information that investors do not have. Journal of Financial Economics, 13(2), 187-221. https://doi.org/10.1016/0304-405X(84)90023-0 
Olwale, F., and Asah, F. (2011). The Impact of Firm and Entrepreneurial Characteristics on Access toDebt Finance by SMEs in King Williams' Town, South Africa. International Journal of Business and Management 8 (5), 170-179

Ondiege, P. O. (1996). Capital and Performance of Small Enterprises in Kenya. In D. McCormick \& P. O. Pedersen (Eds.), Small Enterprises: Flexibility and Networking in an African Context. Nairobi: Longhorn Publishers.

Palacín-Sánchez, M.J., L. Ramírez-Herrera, and F. di Pietro (2013). Capital structure o MEs in anish regions. Small Business Economics 41(2013), 403-519

Saarani, A., N., and Shahadan, F. (2012). The Determinant of Working Capital Requirements for Enterprise 50 (E50) Firms in Malaysia: Analysis Using Structural Equation Modelling. Scottish Journal of Arts, Social Sciences and Scientific Studies, $5(2), 52-66$.

Trovato, G., and Alfó, M. (2006). Credit rationing and the financial structure of Italian small and medium enterprises. Journal of Aplied Economics, 9(1), 167-184.

Schnabel, J. A. (1992). Small Business Capital Structure Choice. Journal of Small Business Finance, 2(1), 13-21.

Siwadi, P., Mhangami, M. (2011). An analysis of the performance of women entrepreneurs in Multi-currency economy: The case of Midlands province of Zimbabwe: University of Botswana Journal.

Whitley, E., and Ball, J. (2002). Statistics Review 4: Sample Size Calculations. Critical Care. Retrieved from: http://ccforum.com/content/6/4/335

Wintoki, M. B., Linck, J. S., and Netter, J. M. (2012). Endogeneity and the dynamics of internal corporate governance. Journal of Financial Economics, 105(3), 581-606.

World Bank. (2017). Survey Methodology: Enterprise Surveys. World Bank. Retrieved from : www.enterprisesurveyes.org/methodology

Wu, J., Song, J., and Zeng, C. (2008). An empirical evidence of small business financing in China. Management Research News, 31(12), 959-975

This is an open-access article published and distributed under the terms and conditions of the $(\mathrm{cc}) \mathrm{EY}$ Creative Commons Attribution 4.0 International License of United States unless otherwise stated. Access, citation and distribution of this article is allowed with full recognition of the authors and the source.

Authors seeking to publish with an International Peer Reviewed Journal should consider www.ijcab.org by writing to the Editor at editor@ijcab.org. The articles must be quality and meet originality test. 